Article

\title{
In Silico Identification of Cholesterol Binding Motifs in the Chemokine Receptor CCR3
}

\author{
Evan van Aalst, Jotham Koneri and Benjamin J. Wylie * \\ Department of Chemistry and Biochemistry, Texas Tech University, Lubbock, TX 79423, USA; \\ Evan.van-Aalst@ttu.edu (E.v.A.); Jotham.Koneri@ttu.edu (J.K.) \\ * Correspondence: Benjamin.J.Wylie@ttu.edu
}

check for updates

Citation: van Aalst, E.; Koneri, J.; Wylie, B.J. In Silico Identification of Cholesterol Binding Motifs in the Chemokine Receptor CCR3. Membranes 2021, 11, 570. https:// doi.org/10.3390/membranes11080570

Academic Editors: Yosuke Senju and Shiro Suetsugu

Received: 13 June 2021

Accepted: 22 July 2021

Published: 28 July 2021

Publisher's Note: MDPI stays neutral with regard to jurisdictional claims in published maps and institutional affiliations.

Copyright: (c) 2021 by the authors. Licensee MDPI, Basel, Switzerland. This article is an open access article distributed under the terms and conditions of the Creative Commons Attribution (CC BY) license (https:// creativecommons.org/licenses/by/ $4.0 /)$.

\begin{abstract}
CC motif chemokine receptor 3 (CCR3) is a Class A G protein-coupled receptor (GPCR) mainly responsible for the cellular trafficking of eosinophils. As such, it plays key roles in inflammatory conditions, such as asthma and arthritis, and the metastasis of many deadly forms of cancer. However, little is known about how CCR3 functionally interacts with its bilayer environment. Here, we investigate cholesterol binding sites in silico through Coarse-Grained Molecular Dynamics (MD) and Pylipid analysis using an extensively validated homology model based on the crystal structure of CCR5. These simulations identified several cholesterol binding sites containing Cholesterol Recognition/Interaction Amino Acid Consensus motif (CRAC) and its inversion CARC motifs in CCR3. One such site, a CARC site in TM1, in conjunction with aliphatic residues in TM7, emerged as a candidate for future investigation based on the cholesterol residency time within the binding pocket. This site forms the core of a cholesterol binding site previously observed in computational studies of CCR2 and CCR5. Most importantly, these cholesterol binding sites are conserved in other chemokine receptors and may provide clues to cholesterol regulation mechanisms in this subfamily of Class A GPCRs.
\end{abstract}

Keywords: GPCR; CCR3; chemokine receptor; cholesterol; CRAC motif; CARC motif; Molecular Dynamics; Pylipid

\section{Introduction}

G protein-coupled receptors (GPCRs) are integral membrane proteins comprising seven transmembrane alpha helices (TM), three extracellular (EC), and three intracellular (IC) loops involved in ligand-binding and G protein docking [1]. Chemokine receptors are a subfamily of Class A GCPRs expressed by immune cells that induce chemotaxis of the expressing cell through the binding of small protein agonists to the receptor's orthosteric binding pocket [2]. Chemokines contain structural disulfide bond motifs formed by $\mathrm{N}$ terminal cysteines that dictate subfamily: $\mathrm{CC}$ motif, $\mathrm{CXC}$ motif, $\mathrm{CX}_{3} \mathrm{C}$ motif, and $\mathrm{XC}$ motif [3]. The cognate receptor is therefore defined based on the native ligand(s). Of the chemokine receptors, CCR5 and CXCR4 are best understood given their known critical role in cellular human immunodeficiency virus (HIV) entry [4,5]. Cholesterol binding and dynamic dimerization sites were observed in both receptors from MD simulations [6].

Lipid modulation of GPCR function is well documented and includes anionic phospholipids such as phosphatidyl serine (PS) [7] and phosphatidylinositol-4,5-bisphosphate $\left(\mathrm{PIP}_{2}\right)$ [8] as well as cholesterol [9]. Cholesterol is an allosteric modulator of function and the dynamic glue for GPCR dimerization [9-13]. However, in vitro molecular investigation of dynamic lipid-receptor interactions is quite difficult as techniques such as NMR are limited by heterologous protein yield and stability. Thus, molecular details are largely derived from cholesterol co-crystallization in GPCR crystal structures, which, while informative, do not encode dynamic information. A GPCR-specific Cholesterol Consensus Motif (CCM) was identified in $\beta_{2} A R$ [6] and is conserved in $21 \%$ of Class A GCPRs but absent from chemokine receptors [12]. 
The Cholesterol Recognition/Interaction Amino Acid Consensus (CRAC) motif is a linear cholesterol binding motif characterized as $\mathrm{L} / \mathrm{V}-\mathrm{X}_{1-5}-\mathrm{Y}-\mathrm{X}_{1-5}-\mathrm{R} / \mathrm{K}$, first identified in the peripheral-type benzodiazepine receptor $[14,15]$. The reverse sequence, deemed the CARC motif, was later uncovered in the nicotinic acetylcholine receptor and found to have a sequence of $\mathrm{R} / \mathrm{K}-\mathrm{X}_{1-5}-\mathrm{Y} / \mathrm{F}-\mathrm{X}_{1-5}-\mathrm{L} / \mathrm{V}[15,16]$. These motifs are found in a wide range of membrane proteins [17], including membrane scaffold proteins [18], HIV membrane fusion proteins [19], and GPCRs [20]. CRAC/CARC motifs provide the ability to define binding sites into easily translatable motifs, but the applicability of such endeavors in GPCRs is still debated [21]. Indeed, cholesterol is known to crystallize bound to GPCRs lacking a CCM, CRAC, or CARC motif $[22,23]$ and does not always occupy such motifs even when present $[24,25]$. In chemokine receptors, cholesterol crystalized with CCR9 localized on TM7 [26], but did not appear to bind to the crystal structure of CCR5 [27] or CXCR4 [28], despite inclusion in the lipidic cubic phase. More recently, the Cryo-EM structure of CXCR2 was solved, where cholesterol was located in a pocket formed by TMs 2,3 , and 4 [29]. Computationally, interactions are also typically evaluated on a case-by-case basis [9-11,13]. The degree of conservation of potential cholesterol binding motifs within the chemokine receptor subfamily is therefore unknown, and classification may therefore be a worthwhile endeavor.

Molecular Dynamics (MD) simulations are a useful tool for studying such GPCR-lipid interactions. Coarse-grained (CG) MD facilitates the analysis of dynamic interactions on timescales that are typically too computationally demanding to perform on atomistic systems. Such approaches have been implemented to good effect in defining lipid-protein binding sites [30-35]. Computation approaches are not, however, limited to defining the locus of lipid-protein interactions. Computation-based drug design makes use of docking suites such as AutoDock [36] and HADDOCK [37] to identify ligand-receptor interactions using experimentally determined structures. Positive hits can be further characterized via MD [38]. So-called rational drug design [39] remains a promising methodology for the development of GPCR-targeting pharmaceuticals. Such computational approaches comprise a critical role in pursuit of this goal.

CCR3 is a chemokine receptor expressed by eosinophils and other immune cells. Binding of its peptide agonists CCL11, 24, 26, and others induces chemotaxis of the expressing cell [40]. CCR3 therefore plays major roles in asthma [41], rheumatoid arthritis [42], and eosinophilic esophagitis [43] as well as cancer metastasis [44-47]. However, there is no known structure of CCR3, and little is known about how the bilayer environment influences CCR3 function. In this vein, we leverage $\mu$ s timescale CGMD simulations in the Groningen Machine for Chemical Simulations (GROMACS) [48] using the Martini2.2 forcefield [49-51] to investigate CCR3 behavior and plasticity in environments of increasing cholesterol content. We then use Pylipid [30,31,52] analysis of GROMACS simulations to identify lipid-protein contact sites to identify potential cholesterol binding sites in the transmembrane region. Six binding sites were identified with greater than $1 \mu$ s cholesterol residency time at $30 \% w / w$ cholesterol, containing 9 of the 12 CRAC and CARC sites found within CCR3. Using residency time as a criterion, the binding site in the EC clefts of helices 1 and 7 emerged as a site of interest, which will be investigated in future work. Lastly, many of the CRAC/CARC sites identified herein are strongly conserved in other CC and CXC motif chemokine receptors and could therefore serve as a starting place for in vitro and in silico investigation of other systems.

\section{Materials and Methods}

\subsection{CCR3 Homology Modeling and Structure Validation}

The model used in this work was previously presented by van Aalst and Wylie [53]. Here, we present the methodology for the generation and validation of this model in much greater detail. We submitted the full-length CCR3 sequence (Uniprot ID: P51677) to the Baker lab Robetta comparative modeling server [54] using the CCR5 crystal structure PDB 4MBS [27] as the template (Uniprot ID P51681). This template was selected due to the 
sequence similarity to CCR3 of 54\%, 93\% sequence coverage, as well as a Global Model Quality Estimate of 0.71 as reported by the Swiss-Model template search [55]. One hundred models were generated and the top 5 based on internal scoring were displayed by Robetta. These models were manually truncated to residues 23-317, leaving helix 8 but removing error-prone regions that were likely to make modeling difficult (Figure S1). We assessed the overall quality of truncated models using the MolProbity scoring system, compared to the template used for modeling (Table S1) [56]. Ramachandran analysis was performed using MolProbity and PROCHECK [57], and Z-score comparison to experimentally determined structures was performed with ProSa $[58,59]$ for both the selected and truncated model and the CCR5 template (Table S1, Figure S2). Small molecules UCB35625 (ZINC13862637) [60], YM344031 (ZINC209227900) [61], SB328437 (ZINC59618358) [62], CH0076989 (ZINC1000177021) [60], Melatonin (ZINC57060), Serotonin (ZINC57058), LDopa (ZINC895199), Phenylethylamine (ZINC6579654), Dopamine (ZINC33882), Glutamine (ZINC1532526), Histamine (ZINC388081), and Glycine (ZINC465855) were downloaded from the ZINC database (accessed 1 October 2020) [63] (Figure S3) and, along with the CCR3 model, prepared for docking analysis with AutoDock tools from the MGL Tools package (version 1.5.6, Molecular Graphics Lab, Scripps Research Institute, La Jolla, CA, USA) [64]. For CCR3, water was deleted, polar-only hydrogens were added, and Kollman charges were added. For ligands, the ZINC database file was converted to a pdbqt file with no further processing. Docking was performed with AutoDock Vina [36] using an energy range of 4 and an exhaustiveness of 8 . The grid box search space (Table S2) was defined by the identified small molecule agonist/antagonist pocket $Y 41^{1.39}, \mathrm{Y} 113^{3.32}, \mathrm{E} 287^{7.39}$ [60], treated as rigid residues.

\subsection{Coarse-Grained Martini Simulations}

The CCR3 model was inserted into membranes consisting of 1-pamlitoyl-2-oleoylphosphatidylcholine (PC) only, 5\%, 10\%, 15\%, 20\%, and 30\% cholesterol $(w / w)$ using the CHARMM-GUI $[65,66]$ Martini maker $[67,68]$. Bilayers were built into rectangular boxes of size $200 \mathrm{~nm}$ at $310.15 \mathrm{~K}$ and 1 bar by aligning the CCR3 model along the principal z axis, followed by the addition of $150 \mathrm{mM} \mathrm{NaCl}$ with molecular replacement and solvation. For each membrane composition, 5 replicate systems [69] were built de novo using identical parameters. Each replicate was individually energy-minimized and equilibrated before production in the GROMACS (version 2020, GROMACS development teams at the Royal Institute of Technology and Uppsala University, Sweden) [48] using the default settings produced by CHARMM-GUI with the Martini2.2 forcefield [49-51] (University of Groningen, Groningen, Netherlands). Briefly, minimization and equilibration were performed using the Berendensen Barostat [70], v-rescale thermostat, and the reaction-field method to manage electrostatics [71]. Production was carried out with the same parameters except with the Parrinello-Rahman Barostat [72] for $10 \mu$ s per replicate using the Martini2.2 forcefield [49-51]. Molecular dynamics parameter (mdp) files for all minimization and equilibration steps were the standard outputs from CHARMM-GUI. Production mdp files were altered solely to change the number of steps to influence the simulation length. Computational time was provided by NMRbox [73] and the Texas Tech University High Performance Computing Center (HPCC).

\subsection{Receptor-Lipid Analysis}

Root Mean Square Deviation (RMSD), Radial Distribution Function (RDF), and Root Mean Square Fluctuation (RMSF) calculations were performed with the gmx rms, gmx rdf, and gmx rmsf functions in GROMACS, respectively, using the default normalization parameters. Receptor RMSD is output as a function of simulation time per replicate. Replicates were averaged together for presentation. RDF calculations were performed for each lipid species in each replicate with respect to the receptor. Data per replicate were averaged for presentation. RMSF values per residue for each replicate were averaged to generate raw RMSF per residue. The residue average in the $0 \%$ simulation was subtracted 
from the average RMSF per residue of each cholesterol-containing simulation to calculate $\triangle$ RMSF. Lipid-protein contacts and binding site sorting were analyzed using Pylipid ( https:/ / github.com/wlsong/PyLipID; accessed on 1 October 2020, Song, et al. University of Oxford, Oxford, UK, $[30,31,52]$ with interaction cutoffs of 0.5 and $1.0 \mathrm{~nm}$, start and end, respectively, for both cholesterol and PC.

\subsection{Receptor Sequence Analysis}

CRAC and CARC motif [17] sequences were identified in CCR3 using EMBOSS: fuzzpro (European Bioinformatics Institute, Wellcome Genome Campus, Hixton, Cambridgeshire, UK, accessed on 1 February 2021) and mapped onto snake plots using the GPCR Database (accessed on 1 February 2021) for visualization [74]. Amino acid sequences for each CC and CXC chemokine receptor were accessed from the UniProt database (accessed on 1 February 2021) with the following accession numbers: P32246 (CCR1), P41597 (CCR2), P51677 (CCR3), P51679 (CCR4), P51681 (CCR5), P51684 (CCR6), P32248 (CCR7), P51685 (CCR8), P51686 (CCR9), P46092 (CCR10), CXCR1 (P25024), P25025 (CXCR2), P49682 (CXCR3), P61073 (CXCR4), P32302 (CXCR5), and O00574 (CXCR6). Sequence alignment was performed with Clustal Omega 1.2.2 (European Bioinformatics Institute, Wellcome Genome Campus, Hixton, Cambridgeshire, UK) [75] and visualized with ESPript 3.0 (University of Lyon, Lyon, France) [76] (both accessed on 1 February 2021).

\section{Results}

\subsection{Homology Modeling and Validation}

To investigate how cholesterol influences the behavior of CCR3, we employed CoarseGrained Molecular Dynamics (CGMD). MD is a powerful tool to investigate protein-lipid interactions but is typically performed with a crystal, NMR, or Cryo-EM structure. Because no structure of CCR3 exists, we turned to homology modeling. We identified the reported X-ray crystal structure of the highly homologous CCR5, PDB ID 4MBS [27], as the best template candidate using the Swiss-Model template search [55]. CCR3 compared to fulllength CCR5 has a sequence homology of $47 \%$, whereas, compared to the truncated crystal structure, the \% identity is 54\%. CCR5 crystal structures 4MBS and 5UIW [77] displayed identical Swiss-Model Global Mean Quality Estimate (GMQE) scores of 0.71. GMQE denotes the estimated quality of a model generated from the particular template, with a maximum value of one. 4MBS was ultimately selected due to the slightly higher sequence coverage (93\% vs. $92 \%$ ). CCR2 is equivalently homologous but with lower GMQE scores and thus was not selected.

Full-length CCR3 was submitted to the Robetta comparative modeling server [54] using this structure as the template. Of the 100 models generated, the top five were displayed based on internal scoring and truncated to residues 23-317 (Figure S1). The truncated regions typically do not crystallize and therefore are untemplated during comparative modeling, generating regions of high predicted modeling error. The highest average scoring truncated model based on MolProbity scores [56], PROCHECK Ramachandran analysis [57], and ProSa [59] Z-score comparison to experimentally determined X-Ray crystallography and NMR structures was chosen (Figure S2, Table S1). We validated this structure via docking of a known CCR3 agonist (CH0076989) and several antagonists (UCB35625, YM344031, SB328437) [60-62] using Autodock Vina [36]. As a final step, these results were then compared to negative controls that shared some common features with the known ligands (Figure 1b). Structures for all tested small molecules are available along with ZINC database [63] identification numbers (Figure S3). The known small molecules displayed statistically significantly higher affinity compared to the selected controls. Of note, the agonist $\mathrm{CH} 0076989$ displayed lower binding energy than the three antagonists, which is unsurprising given that the template, and therefore our model, is of the inactive conformation. Molecules tested here share a common motif of a central amide group flanked by two bulky halogenated cyclic or aromatic groups. The most similar negative control to these small molecules was melatonin, which consists of the amide group but only 
a single bulky aromatic ring system. Despite this similarity, the calculated binding energy was statistically significantly lower than the lowest known ligand, CH0076989. The docking analysis in conjunction with the model scoring therefore suggests high model quality.

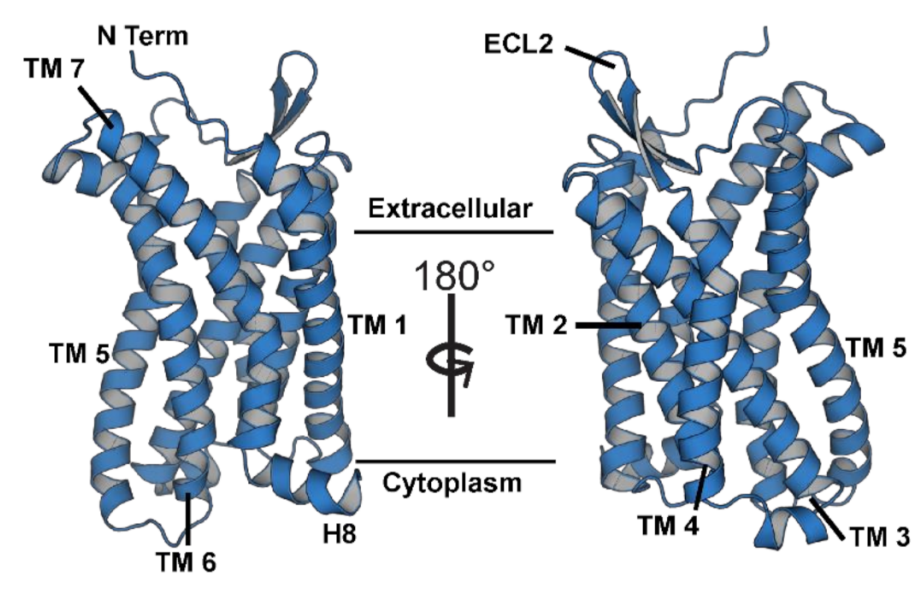

(a)

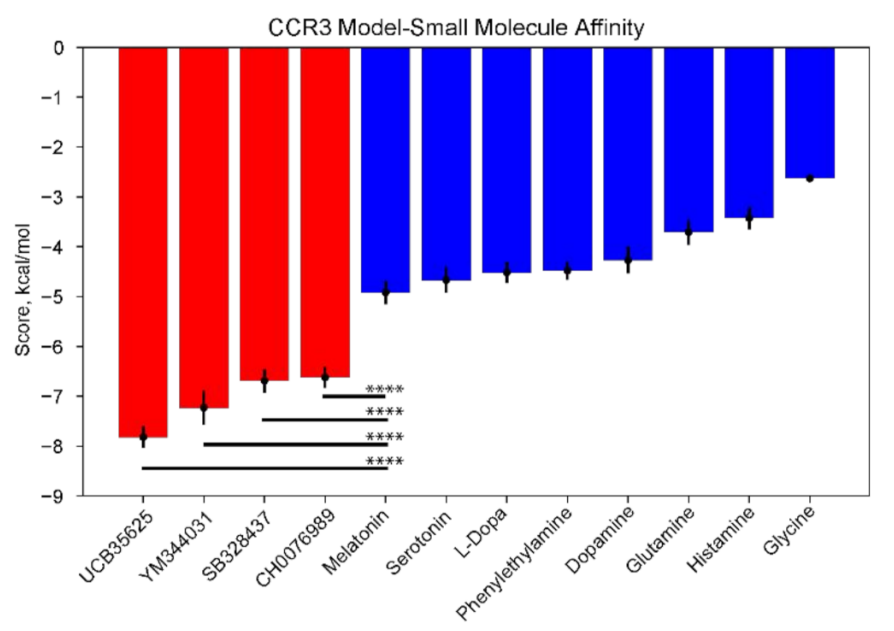

(b)

Figure 1. CCR3 final model and docking validation. (a) TM1-7, H8, and extracellular loop 2 (ECL2, ligand recognition) are highlighted on the CCR3 homology model. (b) Autodock experiments [36,64] between known CCR3-interacting small molecules (red) and several negative controls (blue) suggest high model quality. Data are presented as mean \pm Standard Error of the Mean. Bars indicate statistical significance between the two labeled populations based on the Student $t$-test, where $^{* * * *}$ denotes $p<0.0001$ in the Student $t$-test.

\subsection{CCR3-Cholesterol Behavior in Simulation}

We next sought to leverage this structural model to discern how cholesterol would associate with hypothetical cholesterol binding sites. To this end, we performed CourseGrained MD simulations using the Martini2.2 forcefield [49-51], optimized for lipid-protein interaction quantification. Here, atoms in each residue are grouped into a single backbone bead and 0-3 side chain beads [51]. We inserted our structural model into five replicates of 1-pamlitoyl-2-oleoyl-phosphatidylcholine (POPC, PC) bilayers supplemented with 0 , $5,10,15,20$, and 30\% cholesterol (w/w) (Figure 2). Martini2.2 treats POPC as two polar headgroup beads, two nonpolar glycerol backbone beads, and four apolar beads per lipid tail $[78,79]$. Cholesterol is defined with a polar -OH bead, two apolar tail beads, and a bead for each of the four rings $[79,80]$. The $-\mathrm{OH}$ and ring beads are specially parameterized to model the cholesterol ring system. These assemblies were then minimized and equilibrated before production was carried out for $10 \mu \mathrm{s}$ at $310.15 \mathrm{~K}$. Average RMSDs of each membrane composition as a function of simulation time show that a general equilibrium is quickly reached in all simulation compositions (Figure S4a). Average radial distribution functions (RDF) per composition were calculated for each lipid species, per replicate, relative to the receptor and averaged for each membrane composition. Analysis revealed a higher probability of finding cholesterol molecules around the receptor over both the expected bulk membrane cholesterol concentration (normalized to an RDF magnitude of one) and over PC (Figure S4b). Furthermore, POPC packing behavior was largely unchanged, both throughout the different simulation environments and independent of cholesterol presence. 


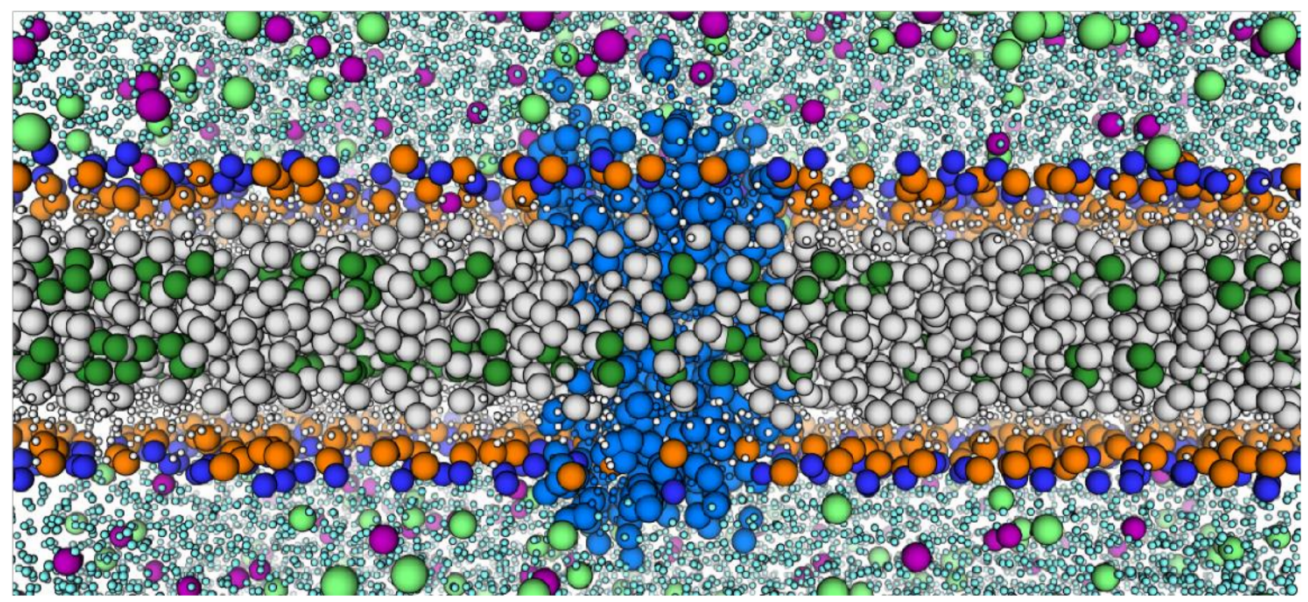

Figure 2. Example of the CCR3 model in a Coarse-Grained System with 30\% cholesterol. CCR3 (slate blue) is surrounded by POPC (large gray beads, large dark blue and orange headgroups) and cholesterol (large green beads for the acyl tails, small white beads for the ring system). Water (cyan), sodium ions (lime), and chloride ions (purple) are represented.

Cholesterol-receptor interactions were then quantified with Pylipid [30,31,52]. Calculated cholesterol residency time by residue in general increases overall as a function of membrane cholesterol content. It is observed to blanket most of the transmembrane portion of the receptor, which is consistent with observations made from computational results of other chemokine receptors (Figure 3a) [10]. Average root mean square fluctuation (RMSF) analysis reveals a trend of increased rigidity with increasing cholesterol \% (Figure $3 \mathrm{~b}$ and Figure S5). Each simulation was compared to the $0 \%$ PC only simulations, with a more negative (blue) value indicating increased rigidity, whereas a more positive (red) value indicates increased flexibility. Enhanced rigidity is observed primarily in TM1 and TM5-7. GPCR conformational sampling inhibition by cholesterol has been observed in $\beta_{2} \mathrm{AR}$ [81]; thus, we hypothesize that the same is occurring in CCR3 based on our data. Ostensibly, this would drive conformational equilibrium towards a state that will more favorably bind the ligand. In the $15 \%$ simulation, we observed an inflection point in both cholesterol residency time and $\triangle$ RMSF. 

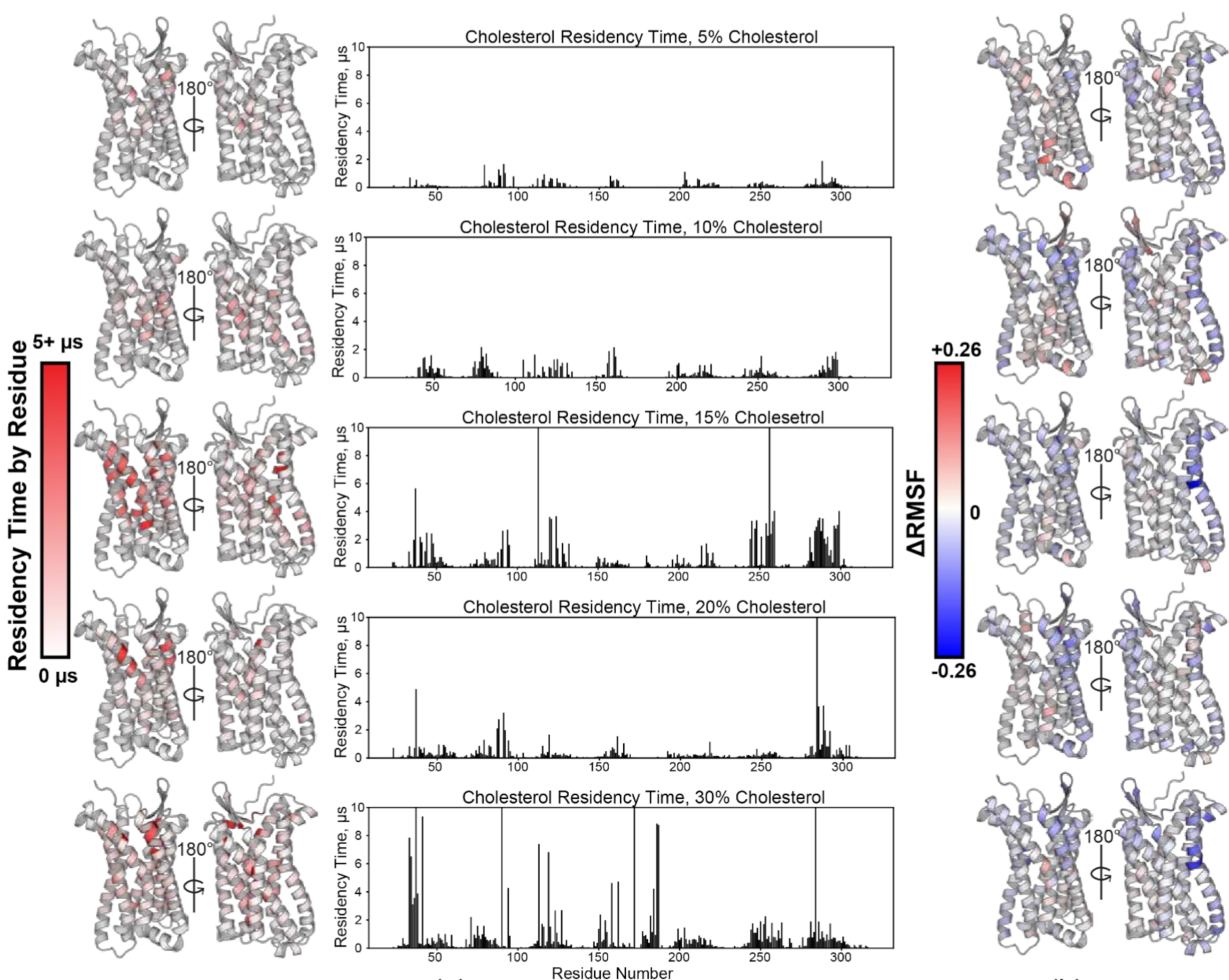

(a)

(b)

Figure 3. Analysis of cholesterol-titrated Coarse-Grained MD simulations. (a) Heatmaps of calculated cholesterol residency times per residue (left) paired with the same values plotted as a function of residue number (right) for the $5 \%$ cholesterol simulations (top) through the $30 \%$ cholesterol simulations (bottom). (b) $\Delta$ Root Mean Square Fluctuation ( $\triangle$ RMSF) calculations reveal sites of structural plasticity (red) and rigidity (blue) mapped onto the model monomer as a function of residue number for the $5 \%$ (top) through $30 \%$ (bottom) cholesterol simulations.

\subsection{Pylipid Predicts Cholesterol Binding Sites in CCR3 Populated with CRAC and CARC Motifs}

Pylipid-predicted binding sites were more or less equivalent across membrane compositions (i.e., the predicted sites contain the same core residues), though some site swapping of peripherally related residues was observed (Figure 4a and Figure S6). Nonetheless, broadly defined binding sites conformed to previous computational studies of chemokine receptors (discussed below). This implies non-stochastic packing around the receptor, which corroborates observations made from RDF data. The grooves between extracellular (EC) sides of TM1/7 (Figure 4, orange) and TM6/7 (Figure 4, dark blue) may be functionally crucial based upon the residency time predicted by Pylipid analysis. Moreover, the $10 \mu$ s and $8.7 \mu$ s residency times for $20 \%$ and $30 \%$ cholesterol, respectively, promote the TM1/7 site as a candidate for future experimental interrogation. Identification of Cholesterol Recognition/Interaction Amino Acid Consensus (CRAC, L/V-X $\mathrm{X}_{1-5}-\mathrm{Y}-\mathrm{X}_{1-5}-\mathrm{R} / \mathrm{K}$ ) motifs $[14,15]$, or the reverse, CARC motifs $\left(\mathrm{R} / \mathrm{K}-\mathrm{X}_{1-5}-\mathrm{Y} / \mathrm{F}-\mathrm{X}_{1-5}-\mathrm{L} / \mathrm{V}\right)[15,16]$, is a typical starting point for cholesterol binding site identification. CCR3 contains four CRAC sites and eight CARC sites (Figure S7a,b). Interestingly, all of the populated binding sites except TM6/7 contained at least one CRAC/CARC motif, comprising 9 of the 12 sites found 
within CCR3 (Figure 4b). The remaining sites (Figure S7c) sorted into EC and intracellular (IC) Pylipid-predicted binding sites integrating components from TM3, 4, and 5. However, cholesterol residency in those sites was statistically insignificant relative to simulation noise (Figure S8). R2025.41 to L208 5.47 , which were highly rigid according to $\triangle$ RMSF calculations, existed within the TM3/4/5 EC site (dark teal) but did not strongly interact with cholesterol.

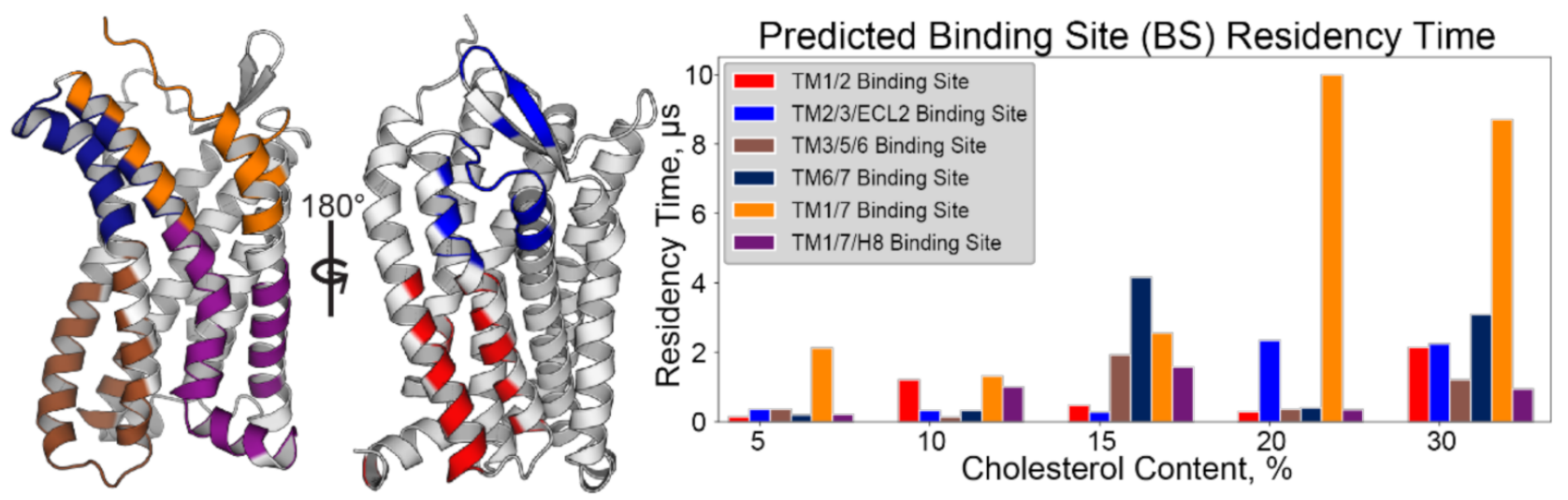

(a)

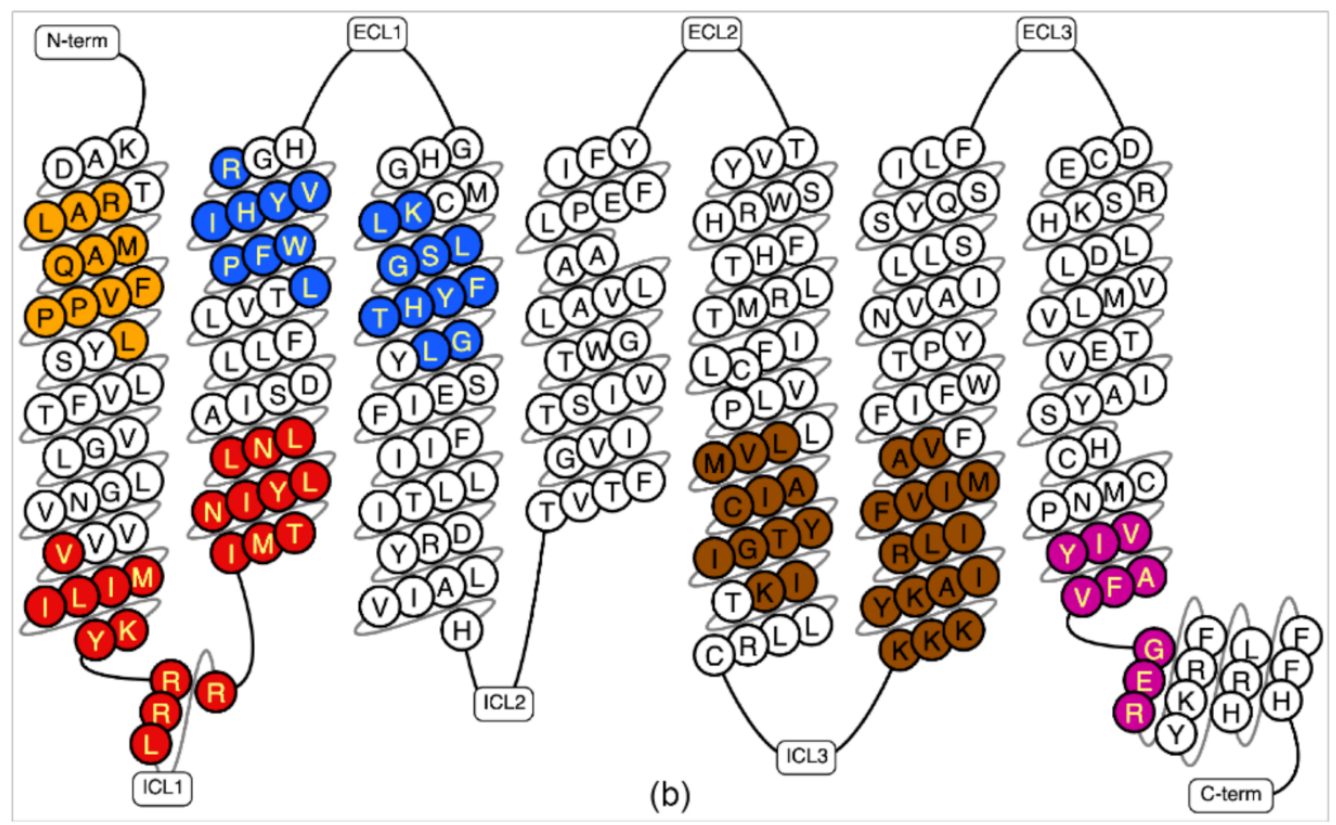

Figure 4. Pylipid-predicted cholesterol binding sites are conserved across membrane conditions and populated with CRAC/CARC motifs. (a) Binding sites are mapped onto the model (left), with cholesterol residency time plotted as a function of membrane cholesterol \% (right) for binding sites identified in grooves between TM helices. (b) CRAC/CARC motifs are color-coded by which predicted binding site they are found within, produced using the GPCRdb [74].

\subsection{CARC-Like Motif in the TM1/7 Binding Site}

The binding site between EC TM1 and 7 is perhaps a special case based on the calculated residency time (Figure 4 , orange). Here, the CARC sequence of $\mathrm{R} / \mathrm{K}-\mathrm{X}_{1-5^{-}}$ $\mathrm{Y} / \mathrm{F}-\mathrm{X}_{1-5}-\mathrm{L} / \mathrm{V}$ [17] is identified in TM1 as R30 ${ }^{1.28}-\mathrm{F} 36^{1.34}-\mathrm{L} 40^{1.38}$ (Figure 5a and Figure $\mathrm{S} 7 \mathrm{~b}, \mathrm{c})$. The residues $\mathrm{L} 284^{7.36}, \mathrm{~V} 285^{7.37}$, and $\mathrm{V} 288^{7.40}$ in TM7 are proximal to this motif. Their sidechain methyls likely contribute to the hydrophobic groove between these two helices and are found within this predicted binding site. Further, these residues exhibit relatively low $\mathrm{K}_{\text {off }}$ values, high cholesterol occupancy, and high lipid count at $20 \%$ and $30 \%$ cholesterol content (Figure $5 \mathrm{a}, \mathrm{c}$ ). L284 $4^{7.36}$ has a $\mathrm{K}_{\text {off }}$ of $0.067 \mu \mathrm{s}^{-1}$ at $20 \%$ and $0.002 \mu \mathrm{s}^{-1}$ at $30 \%$. 


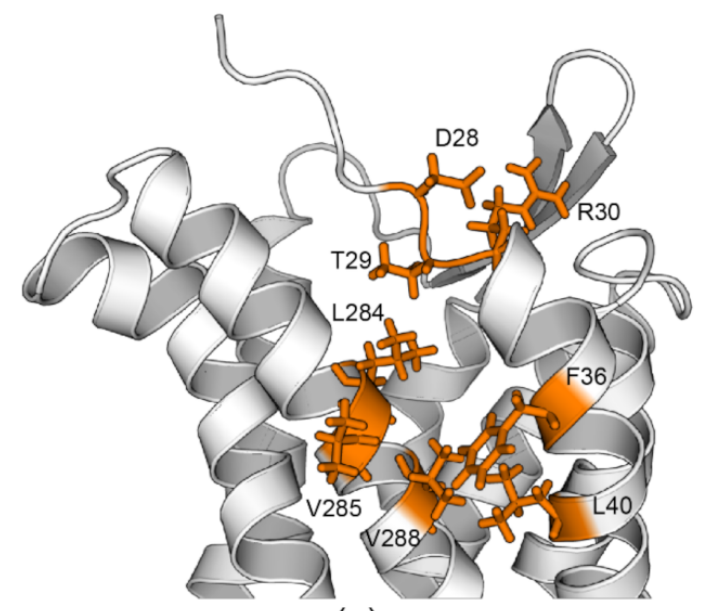

(a)

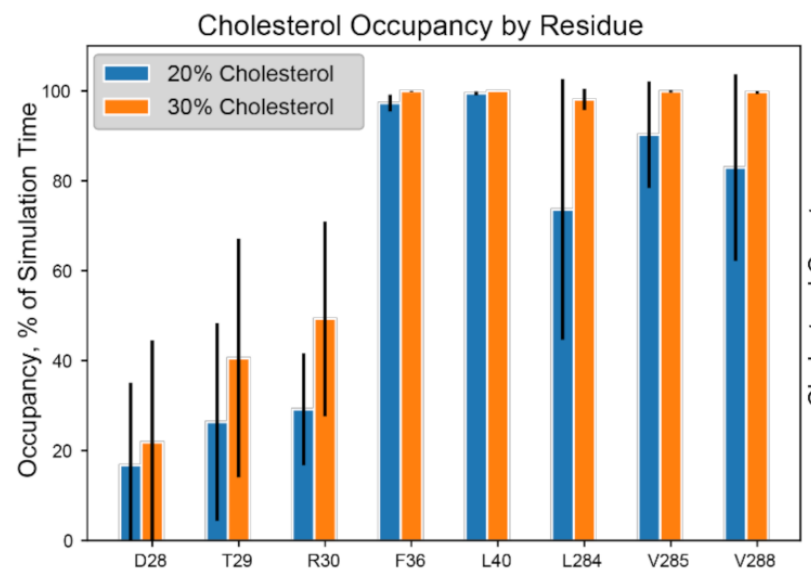

(c)

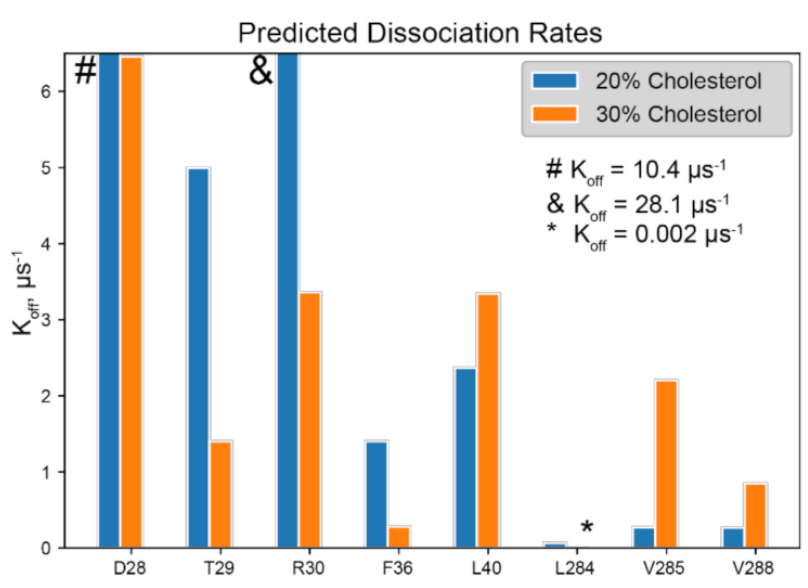

(b)

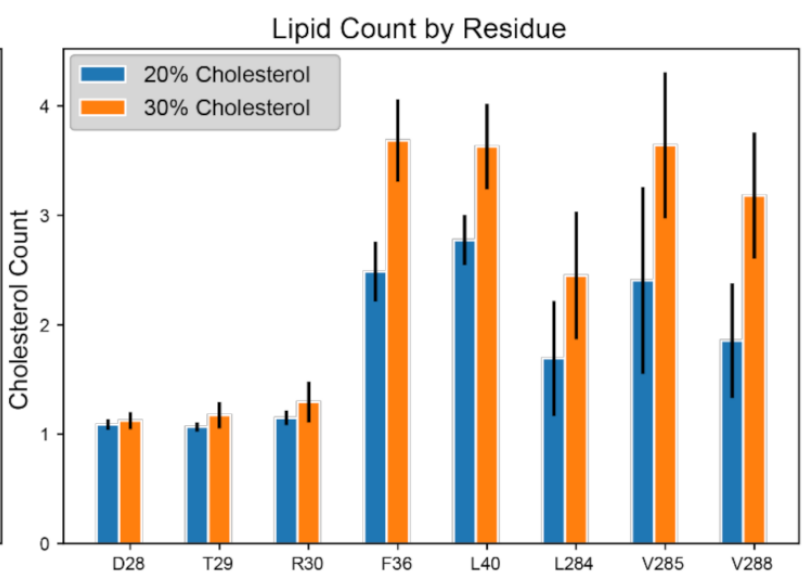

(d)

Figure 5. The TM1/7 site as a potential CCR3 cholesterol binding site. (a) CARC and CARC-adjacent residues identified in the TM1/7 binding site, color coded as in Figure 4. R30 $0^{1.28}-\mathrm{F} 36^{1.34}-\mathrm{L} 40^{1.38}$ form the CARC motif in this binding site. (b) Predicted $K_{\text {off }}$ values, (c) lipid occupancy as a percent of simulation time, and (d) lipid count from the $20 \%$ and $30 \%$ cholesterol simulations. Error bars indicate the standard deviation between replicates. Symbols (\#, \&, and *) denote values outside of the plot view.

Lipid count analysis shows that multiple cholesterols occupy this site throughout the majority of the simulation time at greater than $15 \%$ cholesterol content, correlating to the greater occupancy times for these hydrophobic residues (Figure $5 c, d$ ). Simultaneous occupation of this site is likely, and therefore F36 $6^{1.34}$ may participate in $\pi$ stacking while aliphatic, branched residues in both TM1 and 7 form hydrophobic contacts with cholesterols as the molecules are moving within the site. R30 ${ }^{1.28}$ of the identified CARC site likely forms a hydrogen bond with the hydroxyl group of cholesterol, but ambiguous $\mathrm{K}_{\text {off }}$ values for $\mathrm{R} 30^{1.28}$ ( $\mu$ s regime) hint that hydrogen bond formation may be mediated or transient (Figure $5 b$ ). However, hydrogen bond formation between cholesterol and protein may not be limited to $\mathrm{R}$ and $\mathrm{K}$ residues [15]. The sidechains of D28 ${ }^{1.26}$ and $\mathrm{T} 29^{1.27}$ are both positioned to form hydrogen bonds with cholesterol molecules within this groove (Figure 5a,b). However, it is unknown if this exists in vivo and this predicted binding site should be targeted experimentally. Regardless, tight binding is evident for F36 ${ }^{1.34}$, L40 ${ }^{1.38}$, $\mathrm{L} 284^{7.36}, \mathrm{~V} 285^{7.37}$, and V288 $8^{7.40}$. Similar contributions to cholesterol binding were observed in the serotonin receptor $5-\mathrm{HT}_{1 \mathrm{~A}}$, where residues $\mathrm{L}^{7.32}$ and $\mathrm{I}^{7.36}$ in TM7 played a critical role in cholesterol binding in this site [82]. Thus, we hypothesize that the CARC motif and surrounding branched aliphatic residues play a central role as the core of a cholesterol binding site occupied by multiple cholesterols in CCR3. 


\subsection{Rationaliztion of Identified CRAC/CARC Motif Conservation in Other Chemokine Receptors}

The cholesterol recognition motifs identified in CCR3 are not isolated. Indeed, the residues that comprise these motifs are largely conserved in other $\mathrm{CC}$ and $\mathrm{CXC}$ motif chemokine receptors (Figure 6). Unsurprisingly, functional residues in and near these sites are implicated in receptor dimerization, ligand binding, and signal transduction, often with complicated interplay between all three.

The TM1/7 IC binding site (Figure 6b) was previously identified as a putative cholesterol binding site in CXCR4 and CCR5 [11]. Further sequence alignment reveals that this site is largely conserved throughout the entire subclass. Conservation of this site is not surprising given that the aromatic core $\mathrm{Y}^{7.53}$ is from the NPxxY motif, which plays a critical role in the inactive-active conformational exchange [83]. Additionally, there is considerable overlap between the putative residues identified in CXCR4 and CCR5 and the TM1/7 IC binding site observed in this work (Figure 4 purple and Figure S9). Here, it is apparent that the residues identified in that work are largely conserved in all CC and CXC motif receptors, not just CCR3. Surprisingly, the TM1/7 EC site is not well conserved (Figure 6c) despite high cholesterol residency in simulations of CCR2 and CCR5 [10]. It is unclear whether the presence of the CARC motif here is CCR3-specific or if it may play a broader role in chemokine receptor biology.

The TM1/ 2 site is located spatially close to $\mathrm{D} 80^{2.50}$. $\mathrm{D}^{2.50}$ serves two functional roles. During signal transduction, conformational cascades originating from the orthosteric ligand pocket travel to the toggle switch residue $\mathrm{W}^{6.48}$, then $\mathrm{D}^{2.50}$, and finally to intracellular repacking that would accommodate the $G$ protein [84]. Both residues also coordinate allosteric $\mathrm{Na}^{+}$in an inactive-like state [85,86]. It is therefore no surprise that cholesterol as an allosteric modulator would find residence near these key signal transduction residues. The proximity of the TM6/7 binding site (Figure 4, dark blue) to W252 ${ }^{6.48}$ may therefore be significant for a similar reason, though it lacks a CRAC or CARC motif. Overall, this provides a reasonable explanation for the high conservation of these TM1/2 CRAC/CARC motifs in other chemokine receptors (Figure 6d). 


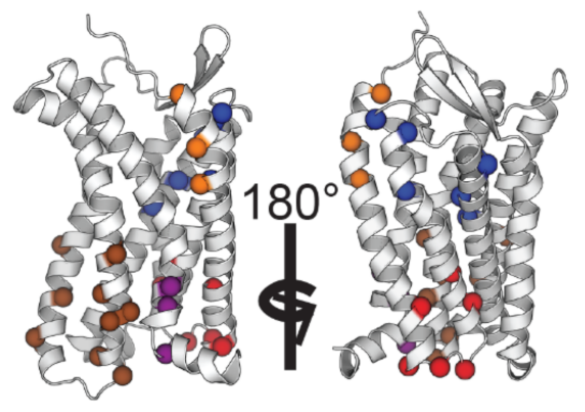

(a)

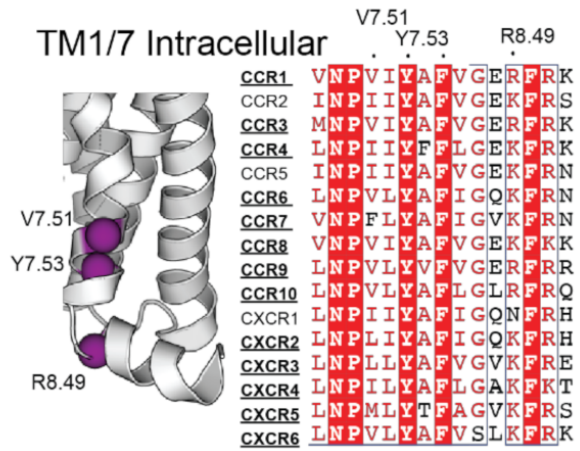

(b)

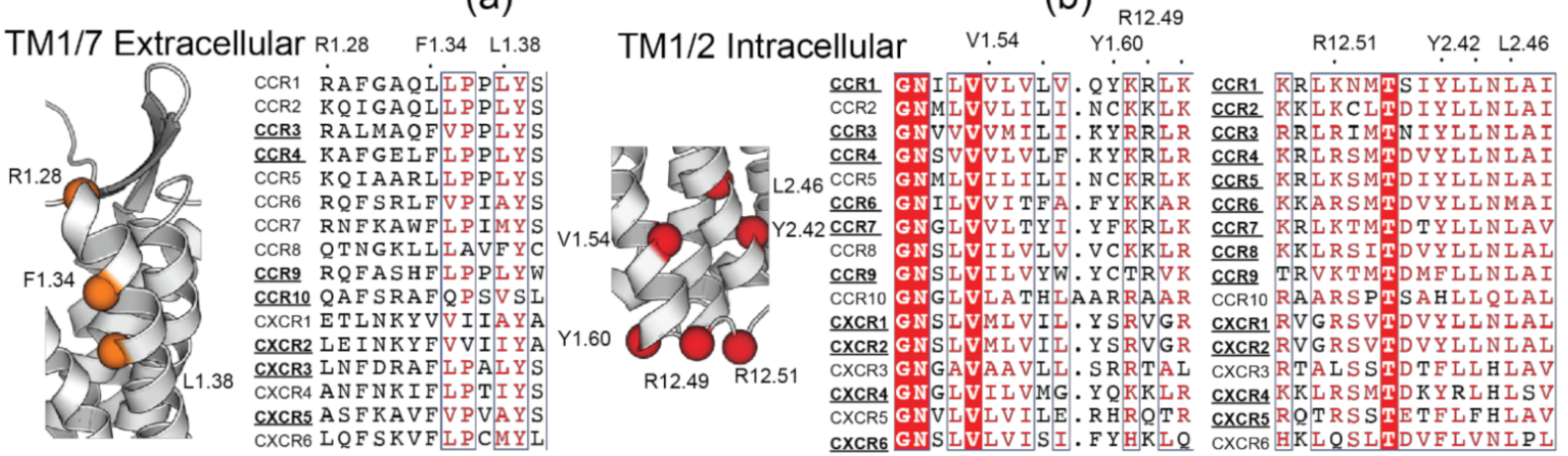

(d)

(c)

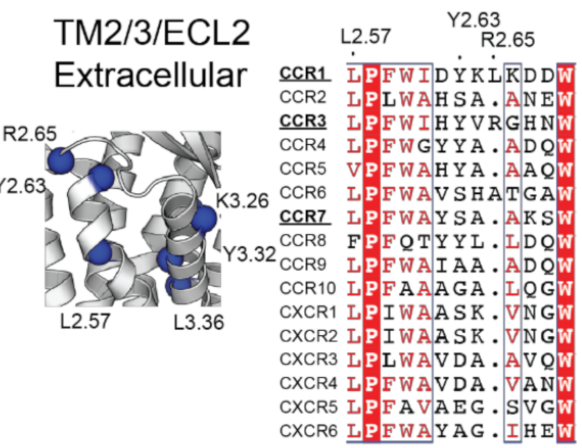

(e)

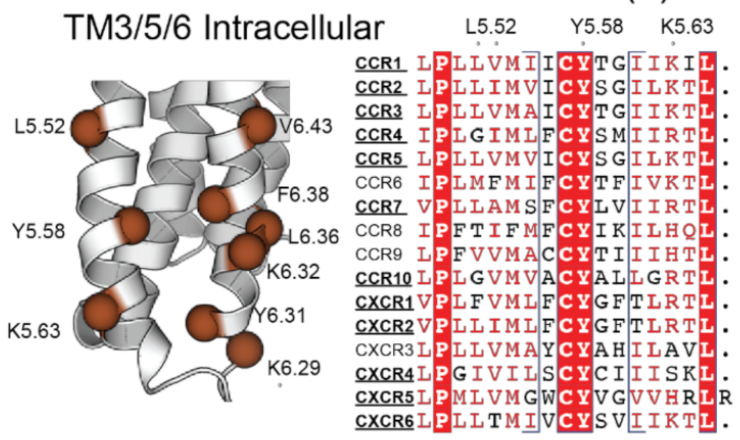

(f)

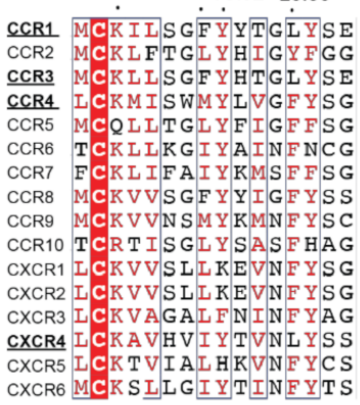

Y6.31 L6.36

K6.29 K6.32 F6.38 V6.43

CCR1 E K R. S CCR2 ER KR R RAVRVIFTIMIVYFI F CCR2 CCR3 KRK. YRAIRLIFVIMAVFFII $\underline{\text { CCR3 }}$ CCR4 EKK. NKAVKMIF A VVVLFI GF CCR4 CCR5 EKRRHRAVRLIFTIMIVYFL F CCR5 CCR6 SKR. HKAIRVII AVVLVFIAC CCR6 CCR7 FER. NKAIKVII AVVVVFIVF CCR7 CCR8 HNK. TKAIRLVIIVVIASLIF CCR8 CCR9 SSK. HKALKVTITVLTVFVLS CCR9 CCR10 PER. RRALRVVVALVAAFVVL CCR10 CXCR1 GOIF HRAMRVIF AVVI I F I C CXCR1 CXCR2 GOK HRAMRVTFAVVI IFITC CXCR CXCR3 ORR. IRAMRLVVVVVVAFA C CXRS $\mathrm{HOT}$. RKA T TTVI I IA A CXCR3 CXCR4 HQK. RKALKTT ILILAFFAC CXCRA

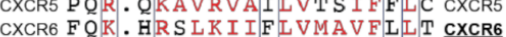

Figure 6. Conservation of CCR3-identified Cholesterol Recognition/Interaction Amino Acid Consensus motif (CRAC) and its inversion (CARC) motifs in other CC and CXC chemokine receptors. (a) Overview of CRAC/CARC residues in Pylipid-predicted binding sites, zoomed and aligned in (b) TM1/7 intracellular side, (c) TM1/7 extracellular side, (d) TM1/2, (e) TM2/3/ECL2, and (f) TM3/5/6. Each residue is color coded by which binding site it resides in. Residues above alignments indicate the CCR3 residue in the CRAC or CARC motif and its position according to the Weinstein-Bellesteros numbering convention [87]. Dots near labeled residues represent other amino acids that could feasibly satisfy the cholesterol motif sequence. Bolded and underlined receptor names indicate conservation of the motif in the receptor, though the residue position may fluctuate. In (f), there are two motifs in TM6 (right). Bolded and underlined receptors on the left of the alignment indicate the site containing $\mathrm{Y}^{6.31}$, while the right contains $\mathrm{F}^{6.38}$. 
The pattern of cholesterol-induced receptor rigidity in TM5 measured via $\triangle \mathrm{RMSF}$ (Figure 3b) mimics binding site residency time in the TM3/5/6 binding site (Figure 4, brown). Thus, we conclude that it is cholesterol occupancy in this site that drives the observed increase in rigidity. Of note, $\mathrm{P} 211^{5.50}$ in the $\mathrm{P} 211^{5.50}-\mathrm{I} 121^{3.40}-\mathrm{F} 248^{6.44}$ motif is directly adjacent to this binding site [88]. This cluster of residues acts as a 'connector' motif reported to link ligand binding at the agonist binding pocket to the NPxxY motif in TM7 during activation [89-91]. The TM2/3/ECL2 binding site follows a similar trend, leading to decreased flexibility in ECL2 (Figure 3b), which is heavily involved in chemokine ligand recognition [92]. These CARC sites are also located spatially nearby $\mathrm{I} 121^{3.40}$ in the PIF motif and $\mathrm{D} 80^{2.50}$. In concert, cholesterol in these two binding sites may therefore play a role in cholesterol-driven conformational selection, which is hypothesized to be a contributing factor to cholesterol-induced changes in ligand affinity [93]. However, conservation of TM2/3/ECL2 CARC sites (Figure 6e) is relatively poor compared to TM3/5/6 (Figure 6f) and may therefore play a secondary or CCR3-specific role to the highly conserved CRAC and CARC motifs in the TM3/5/6 binding site.

\section{Discussion}

\subsection{Cholesterol and Conformational Sampling}

The influence of cholesterol on GPCR conformational dynamics was previously documented [93]. In our simulations, it is possible that the nonlinearity of overall cholesterol binding site residency arises due to concentration-specific conformational sampling whereby cholesterol facilitates the exclusion of conformations energetically unfavorable for ligand-binding. We hypothesize that the concentration of general residency time in the $20 \%$ replicates ( $13 \mu$ s total time) to the TM1/7 EC and TM2/3/ECL2 sites may be due to this concentration-dependent preference. This is in juxtaposition to the $15 \%$ analysis $(\sim 10.5 \mu \mathrm{s}$ total residency time) whereby the residency time is spread over four or more binding sites. We predict that this, in the context of the observed residency time and $\triangle$ RMSF patterns, indicates a direct competitive allosteric cholesterol-CCR3 interaction.

In our simulations, we observe that TM5-7 are prominent sites of increased rigidity. Specifically, residues R202 $2^{5.41}$ to $\mathrm{L} 208^{5.47}$ in TM5 display a significant loss of flexibility. However, these residues are not predicted to be involved in any cholesterol binding sites of note (Figure S8, dark teal). TM5-7 are involved in repacking during Class A GPCR activation, and mutations of key residues in them strongly affect activity, typically by influencing the inactive-active state transition as discussed above [94]. The EC sides of these helices also form the bulk of the orthosteric ligand pocket in Class A GPCRs, in conjunction with TM3 [93]. Kink residues $\mathrm{P}^{5.50}$ in the PIF motif, $\mathrm{P}^{6.50}$, and $\mathrm{P}^{7.50}$ in the NPxxY motif in these helices are essential for coupling of ligand-binding to global conformational changes observed during receptor activation. Thus, we hypothesize that the increasing rigidity of this region through allosteric cholesterol binding prepares the orthosteric pocket to receive the ligand and shifts equilibrium towards a conformation that will be more easily activated by the ligand for signal transduction.

\subsection{Curerent Experimental Evidence of CRAC/CARC Occupancy in Chemokine Receptorss}

While most GPCR structures containing cholesterol appear to favor the CCM, several are found to have CRAC or CARC occupancy [24]: cannabinoid receptor $1\left(\mathrm{CB}_{1}\right)$ (6N4B) [95], the cysteinyl leukotriene receptor 2 (6RZ7) [96], and the formyl peptide receptor 2 (6LW5) [97]. There is therefore direct structural evidence of CRAC and CARC occupancy in Class A GPCRs. To date, however, CCR9 (5LWE) [26] and CXCR2 (6LFM) [29] are the only chemokine receptor structures found to contain any cholesterol. In CCR9, cholesterol localizes to what is referred to as an EC TM6/7 CCM, conspicuously located in space overlapping with the TM6 CARC motif (Figure 6f, far right) and the TM7 CRAC motif (Figure 6b), though we draw no conclusions from this overlap. In CXCR2, cholesterol localizes to a CRAC variant in TM2/3/4 characterized by a Trp residue as the aromatic core 
of the binding site. Additionally, the previously identified putative cholesterol binding site in CXCR4 and CCR5 [11] was accurately predicted here in our own simulations (Figure S9).

Beyond these few examples, very little is to be found concerning cholesterol binding sites in chemokine receptors beyond whole helical contact interfaces in dimerization discussed below. Nevertheless, many chemokine receptors are shown to be sensitive functionally to membrane cholesterol, typically deciphered through cholesterol sequestration [12]. We find it highly unlikely that chemokine receptors as a group would not evolve conserved mechanisms of cholesterol sensitivity. More information is naturally required to draw significant conclusions, but we suggest here that the extrapolation of CCR3 binding site data to other chemokine receptors is not erroneous given that our data also accurately predicted residency in the putative CXCR4 / CCR5 site in the inner leaflet of TM1 and 7.

\subsection{Cholesterol as Dynamic Glue Driving Multimerization}

Ultimately, cholesterol-driven dimerization of CCR3 is beyond the scope of this work. However, a discussion over cholesterol-receptor interaction is nonetheless incomplete without mention of what role these binding sites may play in the phenomenon of receptor multimerization. It is known that CCR3 forms functional dimers and higher-order oligomers, but the role of cholesterol in this phenomenon is unknown [98]. Therefore, the binding sites identified in this work should be considered during future evaluation of CCR3 homo- or hetero-dimerization sites.

It was noted above that the TM1/7/H8 site has already been identified in a number of other chemokine receptors. In the case of the EC TM1/7 site, a previous computational study identified this region as a 'lipid entry portal' in both CCR2 and CCR5, with relatively high cholesterol density on TM1 and TM7 residues in this region [10]. Interestingly, their study also resulted in high density in the groove between the TM6/7 EC side for both receptors and some density in the TM1/7/H8 site on CCR2. Ultimately, it was observed that for both CCR2 and CCR5, TM1 was a homodimerization hotspot in silico, facilitating homodimerization through contacts of TM1/H8 and TM1/H8, TM1/H8 and TM4/5, and TM1/H8 and TM5-7, though a number of less populated dimer interfaces were observed. Lastly, the observed dimer interfaces in their work identified interfaces distinct from those derived from CXCR4 in a prior study, inferring that CC motif receptors form dimers in ways separate from CXC motif receptors [13].

Another study found that the TM3/4/5 and TM5/6 interfaces play a pivotal role in CCR5 homodimerization in vitro and in vivo [99], while the crystal structure helical contact site in complex with the anti-retroviral maraviroc appears to be between TM1/7 of one monomer and TM3/4/5 of the other [27]. In aggregate, these observations suggest a broadly defined swath of helical real estate involved in identified dimer interfaces in CC motif chemokine receptors, corroborated by the observed patterns in cholesterol residency predicted for CCR3 in this work. It is known that CCR3 forms dimers and higher-order oligomers in vivo [98], that dimer formation can influence receptor-ligand affinity [100], and that cholesterol typically drives dimer formation in chemokine receptors $[10,13]$. Thus, the binding sites identified herein will also serve as a starting place to explore the dimerization interfaces of CCR3.

\subsection{Pitfalls in Attempted Sorting of Cholesterol Binding Sites: Rejection of the Bear Thesis}

A recent study made use of Consensus Network Analysis to sort the probability of binding based on cholesterol density in 473 X-ray crystal and Cryo-EM structures [21]. The authors found that $92 \%$ of cholesterol located to 12 clusters and concluded that there were no broadly recurring cholesterol binding motifs in GPCRs. This is not particularly surprising as the supposedly predominant cholesterol binding site, the cholesterol consensus motif, is only found in $21 \%$ of Class A GPCRs [6]. It has also been independently noted that just because a certain motif exists does not mean that it will be occupied [25]. We have observed this as several CARC motifs in CCR3 were not found to have any considerable cholesterol occupancy in our simulations (Figure S8). 
Evolutionary drift of conserved residues is reported even within the CC motif family [101,102]. MD analysis of different chemokine receptors also suggests favored interaction sites that are not necessarily equivalent from receptor to receptor [10]. This would seem to further suggest that classification is indeed pointless, but we instead offer an alternative possibility. While the lack of cohesion in sites observed thus far is frustrating, it is not inconceivable that it would arise from conservation within subsets within each family. This could then explain why the CRAC and CARC motifs observed herein, as well as other sites observed in the literature, such as the CCM in $\beta_{2}$ AR [6], are sometimes conserved and sometimes not. It is evident that further analysis is required, which we certainly find to be a worthwhile pursuit. Thus, we consider the binding sites identified herein to be possibilities not just within CCR3 but chemokine receptors in general. This does not, however, preclude the need for direct validation in any receptor that may appear to conserve a given motif.

\section{Conclusions}

We have generated and validated a homology model of CCR3 based on the CCR5 crystal structure. This model was leveraged to identify cholesterol binding sites from CGMD simulations in a manner similar to other membrane protein systems [30-35]. It was noted that the Pylipid-predicted binding sites contained most of the CRAC and CARC motifs in CCR3. Using sequence alignment, we show that many of these sites are conserved in other chemokine receptors. The binding sites predicted herein are suggested as possibilities which will be used to direct our future work with CCR3 in vitro and could serve the same purpose for other chemokine receptors.

Supplementary Materials: The following are available online at https:/ /www.mdpi.com/article/10 .3390/membranes11080570/s1, Table S1: Model MolProbity Scores, Table S2: Docking Parameters, Figure S1: CCR3 Models and Modeling Error, Figure S2: CCR3 Model 1 Validation and Comparison to CCR5 Template, Figure S3: Small Molecules, Figure S4: RMSD and RDF Analysis, Figure S5: RMSF Analysis, Figure S6: Pylipid-Predicted Cholesterol Binding Sites, Figure S7: Identification of CRAC and CARC Motifs in CCR3, Figure S8: Low Residency CARC Sites, Figure S9: Noncanonical Putative Cholesterol-Binding Site.

Author Contributions: Conceptualization, E.v.A., J.K. and B.J.W.; methodology, E.v.A., J.K. and B.J.W.; software, E.v.A., J.K. and B.J.W.; validation, E.v.A., J.K. and B.J.W.; formal analysis, E.v.A. and B.J.W.; investigation, E.v.A., J.K. and B.J.W.; resources, B.J.W.; data curation, E.v.A., J.K. and B.J.W.; writing—original draft preparation, E.v.A.; writing—review and editing, E.v.A., J.K. and B.J.W.; visualization, E.v.A. and B.J.W.; supervision, B.J.W.; project administration, B.J.W.; funding acquisition, B.J.W. All authors have read and agreed to the published version of the manuscript.

Funding: This research was funded by the National Institute of Health, grant number 1R35GM124979 (Maximizing Investigators' Research Award (MIRA) R35).

Institutional Review Board Statement: Not Applicable.

Informed Consent Statement: Not Applicable.

Data Availability Statement: Data is available upon request from corresponding author.

Acknowledgments: We would like to thank Isaac Eason and Collin Borcik (Texas Tech University) for suggestions in experimental design and analysis and for donation of python data presentation scripts. The computational resources in this study were in part provided by the Texas Tech High Performance Computing Center. This study also made use of NMRbox: National Center for Biomolecular NMR Data Processing and Analysis, a Biomedical Technology Research Resource (BTRR), which is supported by NIH grant P41GM111135 (NIGMS). We acknowledge use of the GPCRdb (https:/ / www.gpcrdb.org; accessed on 1 October 2020).

Conflicts of Interest: The authors declare no conflict of interest. 


\section{References}

1. Rosenbaum, D.M.; Rasmussen, S.; Kobilka, B.K. The structure and function of G-protein-coupled receptors. Nat. Cell Biol. 2009, 459, 356-363. [CrossRef]

2. Stone, M.J.; Hayward, J.; Huang, C.; Huma, Z.E.; Sanchez, J. Mechanisms of Regulation of the Chemokine-Receptor Network. Int. J. Mol. Sci. 2017, 18, 342. [CrossRef]

3. Poeta, V.M.; Massara, M.; Capucetti, A.; Bonecchi, R. Chemokines and Chemokine Receptors: New Targets for Cancer Immunotherapy. Front. Immunol. 2019, 10, 379. [CrossRef]

4. Deng, H.; Liu, R.; Ellmeier, W.; Choe, S.; Unutmaz, D.; Burkhart, M.; Marzio, P.D.; Marmon, S.; Sutton, R.E.; Hill, C.M.; et al. Identification of a major co-receptor for primary isolates of HIV-1. Nat. Cell Biol. 1996, 381, 661-666. [CrossRef] [PubMed]

5. Ma, Q.; Jones, D.; Borghesani, P.R.; Segal, R.A.; Nagasawa, T.; Kishimoto, T.; Bronson, R.T.; Springer, T.A. Impaired Blymphopoiesis, myelopoiesis, and derailed cerebellar neuron migration in CXCR4- and SDF-1-deficient mice. Proc. Natl. Acad. Sci. USA 1998, 95, 9448-9453. [CrossRef]

6. Hanson, M.A.; Cherezov, V.; Griffith, M.T.; Roth, C.B.; Jaakola, V.-P.; Chien, E.Y.; Velasquez, J.; Kuhn, P.; Stevens, R.C. A Specific Cholesterol Binding Site Is Established by the $2.8 \AA$ Structure of the Human $\beta 2$-Adrenergic Receptor. Structure 2008, 16, 897-905. [CrossRef] [PubMed]

7. Dawaliby, R.; Trubbia, C.; Delporte, C.; Masureel, M.; Van Antwerpen, P.; Kobilka, B.B.K.; Govaerts, C. Allosteric regulation of G protein-coupled receptor activity by phospholipids. Nat. Chem. Biol. 2015, 12, 35-39. [CrossRef]

8. Yen, H.-Y.; Hoi, K.K.; Liko, I.; Hedger, G.; Horrell, M.R.; Song, W.; Wu, D.; Heine, P.; Warne, T.; Lee, Y.; et al. PtdIns(4,5)P2 stabilizes active states of GPCRs and enhances selectivity of G-protein coupling. Nat. Cell Biol. 2018, 559, 423-427. [CrossRef] [PubMed]

9. Calmet, P.; Cullin, C.; Cortès, S.; Vang, M.; Caudy, N.; Baccouch, R.; Dessolin, J.; Maamar, N.T.; LeComte, S.; Tillier, B.; et al. Cholesterol impacts chemokine CCR5 receptor ligand-binding activity. FEBS J. 2019, 287, 2367-2385. [CrossRef] [PubMed]

10. Gahbauer, S.; Pluhackova, K.; Böckmann, R.A. Closely related, yet unique: Distinct homo- and heterodimerization patterns of G protein coupled chemokine receptors and their fine-tuning by cholesterol. PLoS Comput. Biol. 2018, 14, e1006062. [CrossRef]

11. Zhukovsky, M.A.; Lee, P.-H.; Ott, A.; Helms, V. Putative cholesterol-binding sites in human immunodeficiency virus (HIV) coreceptors CXCR4 and CCR5. Proteins: Struct. Funct. Bioinform. 2012, 81, 555-567. [CrossRef] [PubMed]

12. Legler, D.F.; Matti, C.; Laufer, J.M.; Jakobs, B.D.; Purvanov, V.; Allmen, E.U.-V.; Thelen, M. Modulation of Chemokine Receptor Function by Cholesterol: New Prospects for Pharmacological Intervention. Mol. Pharmacol. 2017, 91, 331-338. [CrossRef]

13. Pluhackova, K.; Gahbauer, S.; Kranz, F.; Wassenaar, T.A.; Böckmann, R.A. Dynamic Cholesterol-Conditioned Dimerization of the G Protein Coupled Chemokine Receptor Type 4. PLoS Comput. Biol. 2016, 12, e1005169. [CrossRef] [PubMed]

14. Li, H.; Yao, Z.-X.; Degenhardt, B.; Teper, G.; Papadopoulos, V. Cholesterol binding at the cholesterol recognition/ interaction amino acid consensus (CRAC) of the peripheral-type benzodiazepine receptor and inhibition of steroidogenesis by an HIV TAT-CRAC peptide. Proc. Natl. Acad. Sci. USA 2001, 98, 1267-1272. [CrossRef] [PubMed]

15. Fantini, J.; Epand, R.M.; Barrantes, F.J. Cholesterol-Recognition Motifs in Membrane Proteins. Adv. Exp. Med. Biol. 2019, 1135, 3-25. [CrossRef]

16. Baier, C.J.; Fantini, J.; Barrantes, F.J. Disclosure of cholesterol recognition motifs in transmembrane domains of the human nicotinic acetylcholine receptor. Sci. Rep. 2011, 1, 69. [CrossRef]

17. Fantini, J.; Barrantes, F.J. How cholesterol interacts with membrane proteins: An exploration of cholesterol-binding sites including CRAC, CARC, and tilted domains. Front. Physiol. 2013, 4, 31. [CrossRef]

18. Okamoto, T.; Schlegel, A.; Scherer, P.E.; Lisanti, M.P. Caveolins, a Family of Scaffolding Proteins for Organizing “Preassembled Signaling Complexes" at the Plasma Membrane. J. Biol. Chem. 1998, 273, 5419-5422. [CrossRef]

19. Salzwedel, K.; West, J.T.; Hunter, E. A Conserved Tryptophan-Rich Motif in the Membrane-Proximal Region of the Human Immunodeficiency Virus Type 1 gp41 Ectodomain Is Important for Env-Mediated Fusion and Virus Infectivity. J. Virol. 1999, 73, 2469-2480. [CrossRef]

20. Jafurulla, M.; Tiwari, S.; Chattopadhyay, A. Identification of cholesterol recognition amino acid consensus (CRAC) motif in G-protein coupled receptors. Biochem. Biophys. Res. Commun. 2011, 404, 569-573. [CrossRef]

21. Taghon, G.J.; Rowe, J.B.; Kapolka, N.J.; Isom, D.G. Predictable cholesterol binding sites in GPCRs lack consensus motifs. Structure 2021, 29, 499-506.e3. [CrossRef]

22. Shihoya, W.; Nishizawa, T.; Yamashita, K.; Inoue, A.; Hirata, K.; Kadji, F.M.N.; Okuta, A.; Tani, K.; Aoki, J.; Fujiyoshi, Y.; et al. X-ray structures of endothelin ETB receptor bound to clinical antagonist bosentan and its analog. Nat. Struct. Mol. Biol. 2017, 24, 758-764. [CrossRef]

23. Xing, C.; Zhuang, Y.; Xu, T.-H.; Feng, Z.; Zhou, X.E.; Chen, M.; Wang, L.; Meng, X.; Xue, Y.; Wang, J.; et al. Cryo-EM Structure of the Human Cannabinoid Receptor CB2-Gi Signaling Complex. Cell 2020, 180, 645-654.e13. [CrossRef]

24. Jakubík, J.; El-Fakahany, E. Allosteric Modulation of GPCRs of Class A by Cholesterol. Int. J. Mol. Sci. 2021, 22, 1953. [CrossRef]

25. Sarkar, P.; Chattopadhyay, A. Cholesterol interaction motifs in G protein-coupled receptors: Slippery hot spots? Wiley Interdiscip. Rev. Syst. Biol. Med. 2020, 12, e1481. [CrossRef]

26. Oswald, C.; Rappas, M.; Kean, J.; Doré, A.S.; Errey, J.C.; Bennett, K.; Deflorian, F.; Christopher, J.A.; Jazayeri, A.; Mason, J.S.; et al. Intracellular allosteric antagonism of the CCR9 receptor. Nat. Cell Biol. 2016, 540, 462-465. [CrossRef] 
27. Tan, Q.; Zhu, Y.; Li, J.; Chen, Z.; Han, G.W.; Kufareva, I.; Li, T.; Ma, L.; Fenalti, G.; Zhang, W.; et al. Structure of the CCR5 Chemokine Receptor-HIV Entry Inhibitor Maraviroc Complex. Science 2013, 341, 1387-1390. [CrossRef]

28. Wu, B.; Chien, E.Y.T.; Mol, C.D.; Fenalti, G.; Liu, W.; Katritch, V.; Abagyan, R.; Brooun, A.; Wells, P.; Bi, F.C.; et al. Structures of the CXCR4 Chemokine GPCR with Small-Molecule and Cyclic Peptide Antagonists. Science 2010, 330, 1066-1071. [CrossRef] [PubMed]

29. Liu, K.; Wu, L.; Yuan, S.; Wu, M.; Xu, Y.; Sun, Q.; Li, S.; Zhao, S.; Hua, T.; Liu, Z.-J. Structural basis of CXC chemokine receptor 2 activation and signalling. Nat. Cell Biol. 2020, 585, 1-9. [CrossRef]

30. Ansell, T.B.; Song, W.; Sansom, M.S. The Glycosphingolipid GM3 Modulates Conformational Dynamics of the Glucagon Receptor. Biophys. J. 2020, 119, 300-313. [CrossRef]

31. Duncan, A.; Corey, R.A.; Sansom, M.S.P. Defining how multiple lipid species interact with inward rectifier potassium (Kir2) channels. Proc. Natl. Acad. Sci. USA 2020, 117, 7803-7813. [CrossRef]

32. Sengupta, D.; Chattopadhyay, A. Identification of Cholesterol Binding Sites in the Serotonin1A Receptor. J. Phys. Chem. B 2012, 116, 12991-12996. [CrossRef]

33. Ferraro, M.; Masetti, M.; Recanatini, M.; Cavalli, A.; Bottegoni, G. Mapping Cholesterol Interaction Sites on Serotonin Transporter through Coarse-Grained Molecular Dynamics. PLoS ONE 2016, 11, e0166196. [CrossRef]

34. Horn, J.N.; Kao, T.-C.; Grossfield, A. Coarse-Grained Molecular Dynamics Provides Insight into the Interactions of Lipids and Cholesterol with Rhodopsin. Adv. Exp. Med. Biol. 2013, 796, 75-94. [CrossRef]

35. Sejdiu, B.I.; Tieleman, D.P. Lipid-Protein Interactions Are a Unique Property and Defining Feature of G Protein-Coupled Receptors. Biophys. J. 2020, 118, 1887-1900. [CrossRef] [PubMed]

36. Trott, O.; Olson, A.J. AutoDock Vina: Improving the speed and accuracy of docking with a new scoring function, efficient optimization, and multithreading. J. Comput. Chem. 2009, 31, 455-461. [CrossRef]

37. van Zundert, G.; Rodrigues, J.; Trellet, M.; Schmitz, C.; Kastritis, P.; Karaca, E.; Melquiond, A.; van Dijk, M.; de Vries, S.; Bonvin, A.M. The HADDOCK2.2 Web Server: User-Friendly Integrative Modeling of Biomolecular Complexes. J. Mol. Biol. 2016, 428, 720-725. [CrossRef]

38. Souza, P.C.T.; Thallmair, S.; Conflitti, P.; Ramírez-Palacios, C.; Alessandri, R.; Raniolo, S.; Limongelli, V.; Marrink, S.J. Proteinligand binding with the coarse-grained Martini model. Nat. Commun. 2020, 11, 1-11. [CrossRef] [PubMed]

39. Basith, S.; Cui, M.; Macalino, S.J.; Park, J.; Clavio, N.A.; Kang, S.; Choi, S. Exploring G Protein-Coupled Receptors (GPCRs) Ligand Space via Cheminformatics Approaches: Impact on Rational Drug Design. Front. Pharmacol. 2018, 9, 128. [CrossRef] [PubMed]

40. Ge, B.; Wang, M.; Li, J.; Liu, J.; Huang, F. Maltose binding protein facilitates functional production of engineered human chemokine receptor 3 in Escherichia coli. Process. Biochem. 2015, 50, 285-293. [CrossRef]

41. Gauvreau, G.M.; Fitzgerald, J.M.; Boulet, L.P.; Watson, R.M.; Hui, L.; Villineuve, H.; Scime, T.X.; Schlatman, A.R.; Obminski, C.; Kum, J.; et al. The effects of a CCR3 inhibitor, AXP1275, on allergen-induced airway responses in adults with mild-to-moderate atopic asthma. Clin. Exp. Allergy 2018, 48, 445-451. [CrossRef]

42. Katschke, K.J., Jr.; Rottman, J.B.; Ruth, J.H.; Qin, S.; Wu, L.; LaRosa, G.; Ponath, P.; Park, C.C.; Pope, R.M.; Koch, A.E. Differential expression of chemokine receptors on peripheral blood, synovial fluid, and synovial tissue monocytes/macrophages in rheumatoid arthritis. Arthritis Rheum. 2001, 44, 1022-1032. [CrossRef]

43. Dunn, J.L.; Shoda, T.; Caldwell, J.M.; Wen, T.; Aceves, S.S.; Collins, M.H.; Dellon, E.S.; Falk, G.W.; Leung, J.; Martin, L.J.; et al. Esophageal type 2 cytokine expression heterogeneity in eosinophilic esophagitis in a multisite cohort. J. Allergy Clin. Immunol. 2020, 145, 1629-1640.e4. [CrossRef] [PubMed]

44. He, J.; Chen, Y.; Farzan, M.; Choe, H.; Ohagen, A.; Gartner, S.; Busciglio, J.; Yang, X.; Hofmann, W.; Newman, W.; et al. CCR3 and CCR5 are co-receptors for HIV-1 infection of microglia. Nat. Cell Biol. 1997, 385, 645-649. [CrossRef] [PubMed]

45. Jin, L.; Liu, W.-R.; Tian, M.-X.; Jiang, X.-F.; Wang, H.; Zhou, P.-Y.; Ding, Z.-B.; Peng, Y.-F.; Dai, Z.; Qiu, S.-J.; et al. CCL24 contributes to HCC malignancy via RhoB- VEGFA-VEGFR2 angiogenesis pathway and indicates poor prognosis. Oncotarget 2016, 8, 5135-5148. [CrossRef] [PubMed]

46. Ishida, Y.; Kido, A.; Akahane, M.; Kishi, S.; Tsukamoto, S.; Fujii, H.; Honoki, K.; Tanaka, Y. Mesenchymal stem cells up-regulate the invasive potential of prostate cancer cells via the eotaxin-3/CCR3 axis. Pathol. Res. Pr. 2018, 214, 1297-1302. [CrossRef] [PubMed]

47. Jöhrer, K.; Zelle-Rieser, C.; Perathoner, A.; Moser, P.; Hager, M.; Ramoner, R.; Gander, H.; Höltl, L.; Bartsch, G.; Greil, R.; et al. Up-Regulation of Functional Chemokine Receptor CCR3 in Human Renal Cell Carcinoma. Clin. Cancer Res. 2005, 11, $2459-2465$. [CrossRef] [PubMed]

48. Abraham, M.J.; Murtola, T.; Schulz, R.; Páll, S.; Smith, J.; Hess, B.; Lindahl, E. GROMACS: High performance molecular simulations through multi-level parallelism from laptops to supercomputers. SoftwareX 2015, 1-2, 19-25. [CrossRef]

49. Monticelli, L.; Kandasamy, S.K.; Periole, X.; Larson, R.G.; Tieleman, D.P.; Marrink, S. The MARTINI Coarse-Grained Force Field: Extension to Proteins. J. Chem. Theory Comput. 2008, 4, 819-834. [CrossRef]

50. Periole, X.; Cavalli, M.; Marrink, S.; Ceruso, M.A. Combining an Elastic Network with a Coarse-Grained Molecular Force Field: Structure, Dynamics, and Intermolecular Recognition. J. Chem. Theory Comput. 2009, 5, 2531-2543. [CrossRef]

51. De Jong, D.H.; Singh, G.; Bennett, D.; Arnarez, C.; Wassenaar, T.A.; Schäfer, L.; Periole, X.; Tieleman, D.P.; Marrink, S.J. Improved Parameters for the Martini Coarse-Grained Protein Force Field. J. Chem. Theory Comput. 2012, 9, 687-697. [CrossRef] 
52. Song, W.; Corey, R.A.; Duncan, A.L.; Ansell, T.B.; Stansfeld, P.J.; Sansom, M.S. Pylipid: A Python Toolkit for Analysis of Lipid-Protein Interactions from MD Simulations. Biophys. J. 2021, 120, 48a. [CrossRef]

53. Van Aalst, E.J.; Wylie, B.J. Cholesterol is a dose-dependent positive allosteric modulator of CCR3 ligand affinity and G protein coupling. Front. Mol. Biosci. 2021. [CrossRef]

54. Song, Y.; DiMaio, F.; Wang, R.Y.-R.; Kim, D.; Miles, C.; Brunette, T.; Thompson, J.; Baker, D. High-Resolution Comparative Modeling with RosettaCM. Structure 2013, 21, 1735-1742. [CrossRef]

55. Waterhouse, A.; Bertoni, M.; Bienert, S.; Studer, G.; Tauriello, G.; Gumienny, R.; Heer, F.T.; Beer, T.A.P.D.; Rempfer, C.; Bordoli, L.; et al. SWISS-MODEL: Homology modelling of protein structures and complexes. Nucleic Acids Res. 2018, 46, W296-W303. [CrossRef] [PubMed]

56. Williams, C.J.; Headd, J.J.; Moriarty, N.W.; Prisant, M.G.; Videau, L.L.; Deis, L.N.; Verma, V.; Keedy, D.A.; Hintze, B.; Chen, V.B.; et al. MolProbity: More and better reference data for improved all-atom structure validation. Protein Sci. 2017, 27, 293-315. [CrossRef]

57. Laskowski, R.A.; Rullmann, J.A.C.; MacArthur, M.W.; Kaptein, R.; Thornton, J. AQUA and PROCHECK-NMR: Programs for checking the quality of protein structures solved by NMR. J. Biomol. NMR 1996, 8, 477-486. [CrossRef]

58. Sippl, M.J. Recognition of errors in three-dimensional structures of proteins. Proteins: Struct. Funct. Bioinform. 1993, 17, 355-362. [CrossRef] [PubMed]

59. Wiederstein, M.; Sippl, M.J. ProSA-web: Interactive web service for the recognition of errors in three-dimensional structures of proteins. Nucleic Acids Res. 2007, 35, W407-W410. [CrossRef]

60. Wise, E.L.; Duchesnes, C.; da Fonseca, P.; Allen, R.A.; Williams, T.J.; Pease, J.E. Small Molecule Receptor Agonists and Antagonists of CCR3 Provide Insight into Mechanisms of Chemokine Receptor Activation. J. Biol. Chem. 2007, 282, 27935-27943. [CrossRef] [PubMed]

61. Sui, Y.; Zhang, Y.; Dong, C.; Xu, B.; Sun, X. The small molecular CCR3 antagonist YM344031 attenuates neurodegenerative pathologies and improves learning and memory performance in a mouse model of Alzheimer's disease. Brain Res. 2019, 1719, 1-10. [CrossRef] [PubMed]

62. Araújo, J.; Silva, L.; Felix, F.; Camargo, E.; Grespan, R. CCR3 antagonist impairs estradiol-induced eosinophil migration to the uterus in ovariectomized mice. Braz. J. Med. Biol. Res. 2020, 53, e8659. [CrossRef]

63. Sterling, T.; Irwin, J.J. ZINC 15—Ligand Discovery for Everyone. J. Chem. Inf. Model. 2015, 55, 2324-2337. [CrossRef]

64. Harris, R.; Olson, A.J.; Goodsell, D.S. Automated prediction of ligand-binding sites in proteins. Proteins Struct. Funct. Bioinform. 2007, 70, 1506-1517. [CrossRef]

65. Lee, J.; Cheng, X.; Swails, J.M.; Yeom, M.S.; Eastman, P.K.; Lemkul, J.; Wei, S.; Buckner, J.; Jeong, J.C.; Qi, Y.; et al. CHARMM-GUI Input Generator for NAMD, GROMACS, AMBER, OpenMM, and CHARMM/OpenMM Simulations Using the CHARMM36 Additive Force Field. J. Chem. Theory Comput. 2015, 12, 405-413. [CrossRef] [PubMed]

66. Jo, S.; Kim, T.; Iyer, V.G.; Im, W. CHARMM-GUI: A web-based graphical user interface for CHARMM. J. Comput. Chem. 2008, 29, 1859-1865. [CrossRef] [PubMed]

67. Qi, Y.; Ingólfsson, H.I.; Cheng, X.; Lee, J.; Marrink, S.; Im, W. CHARMM-GUI Martini Maker for Coarse-Grained Simulations with the Martini Force Field. J. Chem. Theory Comput. 2015, 11, 4486-4494. [CrossRef] [PubMed]

68. Hsu, P.; Bruininks, B.; Jefferies, D.; de Souza, P.C.T.; Lee, J.; Patel, D.S.; Marrink, S.J.; Qi, Y.; Khalid, S.; Im, W. CHARMM-GUI Martini Maker for modeling and simulation of complex bacterial membranes with lipopolysaccharides. J. Comput. Chem. 2017, 38, 2354-2363. [CrossRef]

69. Knapp, B.; Ospina-Forero, L.; Deane, C.M. Avoiding False Positive Conclusions in Molecular Simulation: The Importance of Replicas. J. Chem. Theory Comput. 2018, 14, 6127-6138. [CrossRef]

70. Berendsen, H.J.C.; Postma, J.P.M.; van Gunsteren, W.F.; di Nola, A.; Haak, J.R. Molecular dynamics with coupling to an external bath. J. Chem. Phys. 1984, 81, 3684-3690. [CrossRef]

71. Hünenberger, P.H.; Van Gunsteren, W.F. Alternative schemes for the inclusion of a reaction-field correction into molecular dynamics simulations: Influence on the simulated energetic, structural, and dielectric properties of liquid water. J. Chem. Phys. 1998, 108, 6117-6134. [CrossRef]

72. Parrinello, M.; Rahman, A. Polymorphic transitions in single crystals: A new molecular dynamics method. J. Appl. Phys. 1981, 52, 7182-7190. [CrossRef]

73. Maciejewski, M.W.; Schuyler, A.; Gryk, M.R.; Moraru, I.; Romero, P.R.; Ulrich, E.L.; Eghbalnia, H.R.; Livny, M.; Delaglio, F.; Hoch, J.C. NMRbox: A Resource for Biomolecular NMR Computation. Biophys. J. 2017, 112, 1529-1534. [CrossRef]

74. Pándy-Szekeres, G.; Munk, C.; Tsonkov, T.; Mordalski, S.; Harpsøe, K.; Hauser, A.; Bojarski, A.; E Gloriam, D. GPCRdb in 2018: Adding GPCR structure models and ligands. Nucleic Acids Res. 2017, 46, D440-D446. [CrossRef] [PubMed]

75. Madeira, F.; Park, Y.M.; Lee, J.; Buso, N.; Gur, T.; Madhusoodanan, N.; Basutkar, P.; Tivey, A.R.N.; Potter, S.C.; Finn, R.D.; et al The EMBL-EBI search and sequence analysis tools APIs in 2019. Nucleic Acids Res. 2019, 47, W636-W641. [CrossRef] [PubMed]

76. Robert, X.; Gouet, P. Deciphering key features in protein structures with the new ENDscript server. Nucleic Acids Res. 2014, 42, W320-W324. [CrossRef]

77. Zheng, Y.; Han, G.W.; Abagyan, R.; Wu, B.; Stevens, R.; Cherezov, V.; Kufareva, I.; Handel, T.M. Structure of CC Chemokine Receptor 5 with a Potent Chemokine Antagonist Reveals Mechanisms of Chemokine Recognition and Molecular Mimicry by HIV. Immunity 2017, 46, 1005-1017.e5. [CrossRef] 
78. Wassenaar, T.A.; Ingólfsson, H.I.; Boeckmann, R.A.; Tieleman, D.P.; Marrink, S. Computational Lipidomics with insane: A Versatile Tool for Generating Custom Membranes for Molecular Simulations. J. Chem. Theory Comput. 2015, 11, $2144-2155$. [CrossRef]

79. Marrink, S.; Risselada, H.J.; Yefimov, S.; Tieleman, D.P.; De Vries, A.H. The MARTINI Force Field: Coarse Grained Model for Biomolecular Simulations. J. Phys. Chem. B 2007, 111, 7812-7824. [CrossRef]

80. Melo, M.N.; I Ingolfsson, H.; Marrink, S. Parameters for Martini sterols and hopanoids based on a virtual-site description. J. Chem. Phys. 2015, 143, 243152. [CrossRef]

81. Jones, A.J.Y.; Gabriel, F.; Tandale, A.; Nietlispach, D. Structure and Dynamics of GPCRs in Lipid Membranes: Physical Principles and Experimental Approaches. Molecules 2020, 25, 4729. [CrossRef]

82. Xu, P.; Huang, S.; Zhang, H.; Mao, C.; Zhou, X.E.; Cheng, X.; Simon, I.A.; Shen, D.-D.; Yen, H.-Y.; Robinson, C.V.; et al. Structural insights into the lipid and ligand regulation of serotonin receptors. Nat. Cell Biol. 2021, 592, 469-473. [CrossRef]

83. Prioleau, C.; Visiers, I.; Ebersole, B.J.; Weinstein, H.; Sealfon, S. Conserved Helix 7 Tyrosine Acts as a Multistate Conformational Switch in the 5HT2C Receptor. J. Biol. Chem. 2002, 277, 36577-36584. [CrossRef]

84. Eddy, M.T.; Lee, M.-Y.; Gao, Z.-G.; White, K.L.; Didenko, T.; Horst, R.; Audet, M.; Stanczak, P.; McClary, K.M.; Han, G.W.; et al. Allosteric Coupling of Drug Binding and Intracellular Signaling in the A2A Adenosine Receptor. Cell 2018, 172, 68-80.e12. [CrossRef]

85. Miao, Y.; Caliman, A.D.; McCammon, J.A. Allosteric Effects of Sodium Ion Binding on Activation of the M3 Muscarinic G-Protein-Coupled Receptor. Biophys. J. 2015, 108, 1796-1806. [CrossRef] [PubMed]

86. White, K.L.; Eddy, M.T.; Gao, Z.-G.; Han, G.W.; Lian, T.; Deary, A.; Patel, N.; Jacobson, K.; Katritch, V.; Stevens, R.C. Structural Connection between Activation Microswitch and Allosteric Sodium Site in GPCR Signaling. Structure 2018, 26, 259-269.e5. [CrossRef] [PubMed]

87. Ballesteros, J.A.; Weinstein, H. [19] Integrated methods for the construction of three-dimensional models and computational probing of structure-function relations in G protein-coupled receptors. Methods Neurosci. 1995, 25, 366-428. [CrossRef]

88. Schönegge, A.-M.; Gallion, J.; Picard, L.-P.; Wilkins, A.D.; Le Gouill, C.; Audet, M.; Stallaert, W.; Lohse, M.; Kimmel, M.; Lichtarge, O.; et al. Evolutionary action and structural basis of the allosteric switch controlling $\beta 2 \mathrm{AR}$ functional selectivity. Nat. Commun. 2017, 8, 1-12. [CrossRef] [PubMed]

89. Picard, L.-P.; Schönegge, A.-M.; Bouvier, M. Structural Insight into G Protein-Coupled Receptor Signaling Efficacy and Bias between Gs and $\beta$-Arrestin. ACS Pharmacol. Transl. Sci. 2019, 2, 148-154. [CrossRef]

90. Rasmussen, S.; DeVree, B.; Zou, Y.; Kruse, A.C.; Chung, K.Y.; Kobilka, T.S.; Thian, F.S.; Chae, P.S.; Pardon, E.; Calinski, D.; et al. Crystal structure of the $\beta 2$ adrenergic receptor-Gs protein complex. Nat. Cell Biol. 2011, 477, 549-555. [CrossRef]

91. Wacker, D.; Wang, C.; Katritch, V.; Han, G.W.; Huang, X.-P.; Vardy, E.; McCorvy, J.D.; Jiang, Y.; Chu, M.; Siu, F.Y.; et al. Structural Features for Functional Selectivity at Serotonin Receptors. Science 2013, 340, 615-619. [CrossRef]

92. Wasilko, D.J.; Johnson, Z.L.; Ammirati, M.; Che, Y.; Griffor, M.C.; Han, S.; Wu, H. Structural basis for chemokine receptor CCR6 activation by the endogenous protein ligand CCL20. Nat. Commun. 2020, 11, 1-9. [CrossRef]

93. Weis, W.I.; Kobilka, B.K. The Molecular Basis of G Protein-Coupled Receptor Activation. Annu. Rev. Biochem. 2018, 87, 897-919. [CrossRef]

94. Dalton, J.A.R.; Lans, I.; Giraldo, J. Quantifying conformational changes in GPCRs: Glimpse of a common functional mechanism. BMC Bioinform. 2015, 16, 124. [CrossRef] [PubMed]

95. Kumar, K.K.; Shalev-Benami, M.; Robertson, M.J.; Hu, H.; Banister, S.; Hollingsworth, S.A.; Latorraca, N.R.; Kato, H.; Hilger, D.; Maeda, S.; et al. Structure of a Signaling Cannabinoid Receptor 1-G Protein Complex. Cell 2019, 176, 448-458.e12. [CrossRef] [PubMed]

96. Gusach, A.; Luginina, A.; Marin, E.; Brouillette, R.L.; Besserer-Offroy, É.; Longpré, J.M.; Ishchenko, A.; Popov, P.; Patel, N.; Fujimoto, T.; et al. Structural basis of ligand selectivity and disease mutations in cysteinyl leukotriene receptors. Nat. Commun. 2019, 10, 1-9. [CrossRef]

97. Chen, T.; Xiong, M.; Zong, X.; Ge, Y.; Zhang, H.; Wang, M.; Han, G.W.; Yi, C.; Ma, L.; Ye, R.D.; et al. Structural basis of ligand binding modes at the human formyl peptide receptor 2. Nat. Commun. 2020, 11, 1-9. [CrossRef]

98. Song, Y.; Ge, B.; Lao, J.; Wang, Z.; Yang, B.; Wang, X.; He, H.; Li, J.; Huang, F. Regulation of the Oligomeric Status of CCR3 with Binding Ligands Revealed by Single-Molecule Fluorescence Imaging. Biochemistry 2017, 57, 852-860. [CrossRef] [PubMed]

99. Jin, J.; Momboisse, F.; Boncompain, G.; Koensgen, F.; Zhou, Z.; Cordeiro, N.; Arenzana-Seisdedos, F.; Perez, F.; Lagane, B.; Kellenberger, E.; et al. CCR5 adopts three homodimeric conformations that control cell surface delivery. Sci. Signal. 2018, 11, eaal2869. [CrossRef]

100. Salanga, C.L.; O'Hayre, M.; Handel, T. Modulation of chemokine receptor activity through dimerization and crosstalk. Cell. Mol. Life Sci. 2008, 66, 1370-1386. [CrossRef] [PubMed]

101. Taddese, B.; Deniaud, M.; Garnier, A.; Tiss, A.; Guissouma, H.; Abdi, H.; Henrion, D.; Chabbert, M. Evolution of chemokine receptors is driven by mutations in the sodium binding site. PLoS Comput. Biol. 2018, 14, e1006209. [CrossRef]

102. Pelé, J.; Abdi, H.; Moreau, M.; Thybert, D.; Chabbert, M. Multidimensional Scaling Reveals the Main Evolutionary Pathways of Class A G-Protein-Coupled Receptors. PLoS ONE 2011, 6, e19094. [CrossRef] [PubMed] 